\title{
Causes and Solutions: Corruption in Chinese Military Enterprises
}

\author{
Yang Yi \\ Institute of Defence Economics and Management, Central University of Finance and Economics, Beijing, China.
}

How to cite this paper: Yang Yi. (2021)

Causes and Solutions: Corruption in Chinese Military Enterprises. Journal of Humanities, Arts and Social Science, 5(1), 69-80.

DOI: $10.26855 /$ jhass.2021.01.008

Received: January 10, 2021

Accepted: February 8, 2021

Published: February 24, 2021

"Corresponding author: Yang Yi, Institute of Defence Economics and Management, Central University of Finance and Economics, Beijing, China.

Email: yiyang86@msn.com

\begin{abstract}
Since the 1980s, Chinese leadership has promoted a gradual transition from a planned to a market economy, and since the end of the 1990s, this process has been extended to state military enterprises, generating positive results but also numerous problems. The most striking issue is corruption, which has attracted significant attention from the press and public. If not properly addressed, this could jeopardize the development of China's economy and armed forces. Since 2012, following intense anti-corruption activities promoted by Secretary General Xi Jinping, many military company executives have been investigated, resulting in some convictions. These judicial proceedings have highlighted the rampant corruption within the defense industry. This study describes several issues common among the corruption episodes. Specialist industry sources, court judgments, and many journalistic investigations were consulted to analyze two corruption cases between 2013 and 2015. These events saw a subsequent strengthening of the fight against corruption. While the cases analyzed are unique, they contribute to a fuller picture of corruption in China, and this research could be expanded through analyses of other cases.
\end{abstract}

\section{Keywords}

Military Enterprises, Corruption, Chinese, Monopoly, Guanxi (relationships)

\section{Introduction}

This work focuses on corruption in Chinese military companies. It links instances of corruption to transformations that subjected companies to the influence of market dynamics throughout the history of the People's Republic of China (PRC). An aspect to be borne in mind is the interdisciplinary nature of corruption, which requires in-depth knowledge of the PRC's contemporary political history and military, along with expertise in the fields of law, sociology, and economics, and no such study has been conducted in a Western language. During my years of research in Italy and China, I focused on the development of the military sector in the PRC, particularly as it relates to domestic politics and international relations. This work explores China's military evolution with a focus on corruption and the complex challenges facing Chinese society in the coming years.

In China, most military enterprises are owned by the state, but are different to state-owned companies in other sectors. First, a military enterprise's first focus is meeting the needs of the defense sector, not the civil aspects of production. Unlike other state-owned companies, state military industries must satisfy national interests and strategic objectives, rather than focusing solely on economic benefits, whereas other state-owned or private companies could not operate without a profit target. Second, the production of certain military products involves national security and thus highly confidential information. Owing to confidentiality requirements, many perceive military enterprises as a mysterious environment that makes analysis and forecasting difficult. However, military companies often use secrecy 
as a way to circumvent journalistic inquiries, such as by refusing to disclose relevant information to reporters or other public bodies. In these circumstances, the secrecy may also serve to protect possible offenses by Chinese military enterprises. Furthermore, China mostly supplies its military with defense equipment from state military enterprises, and only acquires a few weapons on the international market. In this way, a closed circuit is created, along with a double-track monopoly: the state becomes the main — and, in some cases, only — purchaser from companies, and state enterprises are the only suppliers, reducing the options that competition and its competitive market mechanism should guarantee. Some military products are only developed by a single company, and only bought by the state. Chinese military exports to international markets are limited by national security and the balance of international relations: every year, Chinese arms exports are relatively small. Finally, military companies require huge capital investments, advanced technology, and applied research.

There is limited documentation available regarding corruption in Chinese military companies. The China National Knowledge Infrastructure database, which provides digital copies of research produced in China, shows that articles on the topic have seldom focused on corruption among Chinese military companies. There are no monographs about it, and the few essays available — often only a page or two long - tend to contain propaganda. In addition to limited literature, my study was further complicated by the fact that most related information is kept under military secrecy, and the archives of military companies and military research institutes are not available to civilians.

Despite this, I discovered numerous sources through the Chinese media (including Hong Kong and international media), particularly via investigative journalism. Chinese reporters often link to news and information that would otherwise remain unknown to the public, enabling me to examine the case studies included herein. In addition to analyzing sources, I was able to visit some sites that helped me gain a clearer view of the Chinese military apparatus. However, visits to military companies were quite difficult, with access generally restricted to delegations of state-owned companies. When a visit by an individual is possible, it entails a rigorous access procedure. Despite these difficulties, I was able to visit the production department of Institute X, a military scientific research unit belonging to the China Shipbuilding Industry Group Co., Ltd. This visit was particularly useful in understanding the development process of Chinese military enterprises. Finally, for the two cases studied, I read the court judgments and the company's disciplinary documents. By obtaining a reporter's field interview record, I could also gain understanding of some of the causes of corruption, and the actual situation of the company.

Two cases were studied involving industrial giants: the Anhui industrial conglomerate military enterprise, and AVIC Ltd. The events, which compromised the careers of several business leaders, suggest that the main causes of corruption include the imperfect legal mechanisms established during the reform process, such as the monopoly of state military enterprises; flaws in government-led reorganization, restructuring, and mergers of state-owned military companies; and the compensation of military company managers. This paper also highlights an individualistic element that often underlies corruption, where managers of military companies violate laws and regulations to pursue personal interests. Overall, corruption also seems to be affected by features peculiar to traditional Chinese culture (Luo, 2008).

\section{Historical background}

Before studying the corruption cases, it is first necessary to understand the development of military enterprises in the PRC in light of three historical phases: 1) the foundation of the PRC, the Maoist period, and the influence of the USSR and the planned system; 2) the policy of reform and opening in the 1980s, and military companies' civil activities; and 3) market reforms and corruption from the mid-1990s to today. The third phase deserves most attention, as most significant transformations occurred in the 1990s vis-à-vis the corruption cases discussed here.

The first phase included the first 5-year plan, and the introduction of a series of projects (known as the 156 projects) aimed at modernizing the industrial system, in collaboration with the Soviet Union. Later, the strategy of the so-called "third line" (san xian), a large-scale investment in national defense from 1964 until 1980, showed great promise for China's industrial development.

The second phase focused on policy reform and opening up, begun by the Third Plenary Session of the Eleventh Central Committee of the Communist Party in 1978. The strategy of the "third line" had created a vast military industrial apparatus that was no longer necessary in terms of market demands, as orders for military goods had drastically declined, and many companies were inactive. Military enterprises were thus forced to find alternative means of survival, starting a process of transforming military technology for civilian use - a path defined in official rhetoric as a passage "from the military to the civil" (jun zhuan min). 
The third phase began within the new landscape of international relations between China, Russia, and the West. In the 1980s, the United States (USA) eased restrictions on arms exports to China by opening a phase of technical-military cooperation, a period known as the "honeymoon between China and the United States" (Zhong-Mei miyue qi). However, after the Tian'anmen Square events of June 4, 1989, the USA announced cessation of all military exchanges and cooperation with China. On June 26-27, 1989, the Council of the European Community convened a meeting in Madrid and condemned the behavior of the Chinese government, calling for respect for human rights. Diplomatic sanctions included embargoes on arms; the interruption of military cooperation with China; decreases in cultural, scientific, and technological cooperation projects; and the extension of Chinese student visas.

However, with increasing normalization of Sino-Soviet relations and, following the dissolution of the Soviet Union in 1991, China and Russia continued to develop bilateral relations, especially in terms of military cooperation (Wang Mingsong, 2015). In this period, two large-scale reorganizations of the Chinese military industrial system were launched: the first in 1993, and again with more force in 1999. With the reform of state enterprises in 1998, under the leadership of Zhu Rongji, the government seemed to begin to take the problem of corporate corruption seriously (Lin, 1998), which brought severe losses to the State and contributed to unemployment. In the same year, corruption incidents began to emerge involving managers of some military companies, many of which had accumulated high debts compared with their assets (Edward et al., 2002). To overcome such difficulties, the government launched a series of reforms which helped the military sector's economy begin to improve in 2003, and produce considerable profits (Zhang Xingguo, 2008). Since 2007, reforms have mainly focused on promoting the entry of private capital into military industries and encouraging conversion to civilian production; however, these measures are intended to solve the organizational and financial problems of military companies, not substantially fight corruption. After studying the history of these Chinese military enterprises and analyzing relevant information, corruption appears to be due to the imperfect mechanisms established during the reform process. Corruption also seems to arise from the influence of characteristics unique to traditional Chinese culture.

\section{Two examples of corruption in military industrial enterprises}

The following two cases are used because they share some typical characteristics. First, the Anhui military industry group is the largest provincial-level local military industry enterprise by volume of investments, while AVIC Heavy Machinery Co. Ltd. is under the flag of the China Aviation Industry Group (AVIC), which is subordinate to 12 large military industrial groups in China. Second, the products of these two military enterprises involve weapons and equipment in different fields: army and air force. Third, this was the first time since the China Community Party (CCP) increased its anti-corruption efforts in 2012 that corrupt military enterprises were publicly reported by the media on a large scale. The whole process lasted from 2013 to 2015. Therefore, understanding the reasons for corruption in military enterprises can be summed up by studying and analyzing these two cases.

\subsection{Corruption in the Anhui military industry group}

In December 2014, the court of the city of Huainan issued a final verdict in the case of Huang Xiaohu, Secretary and President of the Anhui military industry group, finding he had used his position to illegally obtain more than 31 million RMB, and sentencing him to 19 years in prison. The Anhui military industry group (hereafter "Anhui") is a large, state-owned military enterprise, supported by the Anhui Provincial Government, and the case captured the public's attention due to the bribes and corruption that exposed many problems within the Chinese military enterprise system. Huang's testimony during the case offered an opportunity for deeper reflection regarding corruption in military enterprises in the PRC. The company's history, and events involving Huang and two other top executives, Zhang Youren and Chen Shengtian, are described below.

\subsection{Huang Xiaohu and corruption during his tenure}

Between 2010 and 2013, Anhui was the subject of much media and public attention after reports of bribes and corruption that highlighted problems with the management of Chinese military enterprises. The main figure in this scandal was Huang Xiaohu. Born in January 1963, he served as economic director and head of Foreign Trade in the Municipal Committee of Bengbu between 1999 and 2012; director of a cigarette factory in Chuzhou between 2002 and 2005; and president of Anhui between 2010 and 2013. Three years after its launch in February 2010, on January 29, 2013, the Anhui disciplinary committee accused Haung of violating articles 382 and 385 of the Chinese Criminal Law Code, initiating a judicial investigation. On December 26, 2014, the Huianan city court issued a verdict in the case, sentencing Huang to 19 years in prison and confiscating his personal possessions valued at more than 2 million 
RMB. Over the course of the investigation, however, Huang's testimony highlighted the involvement of other important characters. His revelations were a major factor in the trial, and acted in mitigation of his sentence. According to the prosecutor's office, from 1999 to 2013, Huang abused his power to illegally obtain more than 31.6 million RMB (approximately US\$4.6 million): 9.6 million yuan as a result of corruption, 2.5 million RMB originated from bribes, and 5.4 million yuan from embezzlement.

The press also identified other cases in which Huang made use of bribes, to the value of 14.5 million RMB. In December 2009, with the help of Mr. Liang, the president of a mining group in Shandong, Huang bought two coal mines. As a token of thanks, he sent his wife to Hong Kong to make direct transfers into Liang's account totaling 10 million RMB. In 2006, Huang bought a $60 \%$ stake in a Hongyang coal mine in the city of Huaibei. To thank the key figure in this exchange, Mr. Liu (the former deputy mayor of the city of Bengbu), Huang paid him 4.5 million RMB.

During the investigation, Huang's statements also highlighted the involvement in corruption of former president of Anhui, Zhang Youren, and director, Chen Shengtian. On June 30, 2014, Zhang was tried by the Fuyang city court on three charges: corruption, misappropriation, and using his influence for corrupt purposes. According to the prosecution's allegations, from 1995 to February 2010, Zhang benefited from his roles as vice president, general manager, and chairman of the Dongfang machinery factory group, exploiting various cooperation projects, land transfers, and material supplies to third parties in exchange for bribes totaling 8.3 million RMB (about US $\$ 1.2$ million). Zhang became vice president and general manager of Anhui in February 2006, and president of the Lei'An, a subsidiary of the conglomerate; thereafter, Zhang further benefited from his position by issuing fraudulent invoices, thus appropriating assets totaling 890,000 RMB (about US\$130,000). Through illicit trafficking, Zhang also illegally seized 1.95 million RMB, and continued to use his influence after retiring to guarantee benefits to third parties during the second half of 2010, accepting bribes worth 200,000 RMB. The prosecutor claimed that the total from Zhang's crimes exceeded 8.3 million RMB.

Zhang did not object to the court, nor did his defense attorney object the alleged crimes and genuineness of the evidence; however, the attorney did not agree with some of the facts. According to the defense attorney, the goods and favors that Zhang received after retirement should not have been considered intentional bribery or use of his personal influence for corrupting purposes; rather, the 890,000 RMB received by Lei'an Electronics could be considered an "unsuccessful investment attempt" from which Zhang did not profit personally. However, the prosecution pointed out that the 890,000 RMB from Lei' an Electronics was later transferred entirely to the accounts of Zhang's private companies, and that continuity therefore existed between Zhang's activities in service and after retirement.

On October 9, 2013, the former director of Anhui, Chen Shengtian, was prosecuted for an alleged case of corruption related to the group's business and Zhang, this time in Hefei city court. According to the allegations, since July 2006, Chen was responsible for the company's activities and logistics maintenance work. He initially brought the company into debt, and during the repayment period from July 2008 to September 2009, he issued false invoices to replace missing finances, appropriating nearly 200,000 RMB. According to his confession in early 2009, when he accompanied President Zhang to inspect the company's machinery, Chen suggested using research funds to purchase machinery but did not receive confirmation. Later, he asked Zhang again to purchase machines with those funds, and suggested he could also pay the down payment on a house for Zhang's son; Zhang then agreed and offered to pay Chen 100,000 RMB. Chen later prepared three blank invoices totaling 555,000 RMB and showed them to Zhang for approval of consulting fees and to provide a refund to another branch account. According to the prosecutors, in March 2009, Chen and Zhang confirmed the fraudulent invoices and withdrew public funds from the company's financial accounts. Until March 2010, Chen stole 555,000 RMB from the company, and paid 350,000 RMB to Zhang. Chen's defense lawyer highlighted the secondary role of his client as an accomplice to the crime, noting that Chen confessed to the crimes attributed to him. The lawyer then asked for a lighter sentence of 5-7 years in prison. However, the prosecutor claimed that the defendant had taken advantage of his position to illegally seize state assets totaling 750,000 RMB, and twice proposed false invoices to Zhang; Chen would therefore have been responsible for the actual perpetration of the crime rather than simply being an accomplice. According to the prosecution, his behavior could warrant a sentence of more than 10 years in prison.

A highly collusive mechanism had developed, in which military enterprise officials became the pivot of the relationship between institutions and companies, obtaining benefits via resource allocation, resulting in a system that seriously undermined competition and prevented proper market regulation. The most telling feature in the Anhui case, in comparison to other incidents of corruption in state-owned military enterprises, was the collusion between 
officials and entrepreneurs, and the premeditated nature of corruption, particularly the formation and use of a network of guanxi (relationships) among managers of the company, and between managers and officials, that was created to obtain economic benefits. This damaged free competition, leading to atrophy of vital market functions. If corrupt activities by managers of state-owned military enterprises is not investigated promptly, state property will be damaged and China's economic order will be compromised.

\subsection{Corruption in AVIC Heavy Machinery Co. Ltd.}

On June 4, 2014, AVIC Heavy Machinery Co. Ltd. (hereafter "AVIC Ltd."), the first company in the Chinese aviation sector to be listed on the stock exchange, revealed to the press that it had received a disciplinary inspection notice. The company's deputy general manager, $\mathrm{Wu} \mathrm{Hao}$, and another senior executive, Zhao Guibin, were under investigation and placed under the "dual regulation" regime (shuang gui) on a charge of having committed serious violations. Over the course of 2014, several economic transactions aroused inspectors' suspicions about potential corruption, primarily involving the illicit sale of certain shares of the Xi'an Sanjiao branch, and the appropriation of investments intended for the construction of buildings and development centers within the AVIC Industrial Park in Xi'an.

The following sections detail the history of AVIC Ltd. and the circumstances that led to the investigation against Wu and Zhao.

\subsection{Wu Hao and corruption during his tenure}

Wu Hao was born in 1964 in Sichuan province, graduating in July 1987 from the Polytechnic University of Northwest China, and obtaining a master's degree in business administration at Tsinghua University in January 2005. Wu held many executive positions within AVIC Ltd. over the years, which was rare in the company. He initially worked for the Guizhou Anda branch dedicated to the aeronautics sector, of which he was appointed general manager and vice president. In May 2009, he became deputy general manager of AVIC Ltd. and in December became president and legal representative of the Jiangxi and Wuxi branches. In September 2010, he became president of the Shaanxi Hongyuan branch of Guizhou Anda, and general manager of the Xi'an Tecai branch. As reported on the Xinhua agency's website, in 2013, his annual salary was as high as 630,000 RMB.

On June 4, 2014, AVIC Ltd. announced that it had received a disciplinary inspection notice, for which Wu received precautionary measures and was placed under the "double rule" regime. News of the investigation was first published on the company's website, and on June 10, it was published on the official platform of the Central Commission for the inspection of discipline. On the same day, $21^{\text {st }}$ Century Business Herald Shiji Jingji Bao declared that Wu was suspected of corruption in the illicit sale of shares of the Xi'an Sanjiao branch (AVIC Ltd.'s core site for forging activities) and for taking advantage of his role as president of the Shaanxi Hongyuan branch to divert investments intended for the AVIC Industrial Park.

To better understand this episode and Wu's role in the case, it is useful to briefly reconstruct the history of the affected branches. Xi'an Sanjiao was founded in 2003 following investment of funds by the provincial government of Shaanxi and the municipal government of Xi'an totaling 252 million RMB. Shaanxi Hongyuan was created in 1965 as a branch of AVIC Ltd., specializing in forging. Throughout its 50 years of activity, it made a fundamental contribution to the development of the Chinese aeronautical sector, machinery construction and transport, and electrical industry.

In 2008, the two companies developed an intricate system of cooperation. Xi'an Sanjiao was to become publicly traded by collaborating with Shaanxi Hongyuan, where the latter would invest 40 million RMB (10 million in intangible assets and 30 million in cash) in Sanjiao, becoming its first shareholder, and then register in the stock exchange under its name. However, in 2009, AVIC Ltd. planned a reorganization with Hongyuan becoming a direct subsidiary, arousing further concern around Sanjiao's stock exchange listing. As a result, Sanjiao executives proposed that Hongyuan divest shares that were previously purchased for the Xi'an aerospace investment fund, which the company was apparently interested in buying. A Sanjiao shareholder revealed that, "In that period the agreement with the former managers of AVIC Ltd. foresaw that an action was worth 1.6 RMB. Wu Hao, thinking that the price was too high, proposed to go down to $0.98 \mathrm{RMB}$. Subsequently, the other shareholders suggested to fix it to $1 \mathrm{RMB}$, thus finding an agreement with $\mathrm{Wu}$ Hao and providing for the subsequent transfer of the shares".

In December 2010, as part of this project, Shaanxi Hongyuan withdrew funds from Xi'an Sanjiao, signed an agreement with the invoice fund, and transferred its shares there. An article in 21 Shiji Jingji Bao uncovered these agreements, explaining how Hongyuan had originally invested a total of 40 million RMB in Sanjiao. Subsequently, 
the fund increased its investment in Sanjiao by a total of 50 million RMB, becoming the first shareholder. The most controversial detail revealed through the journalistic investigation was the lack of a written record in the Hongyuan archives on the sale of shares in Sanjiao between the end of 2010 and beginning of 2011. Sun Jibing, deputy general manager of AVIC Ltd., declared to the press, "Usually, if there are transactions that have a significant impact on the company's business, these are communicated through the publication of an announcement. To get to the transfer of shares must be respected a complex and intricate system that regulates the management of investments".

From a procedural viewpoint, the lack of official announcements by AVIC Ltd. was interpreted as a lack of involvement by central company executives in the decision-making processes about Sanjiao's stock transactions. Hongyuan President $\mathrm{Wu}$ was held responsible for this illegal situation and accused of abusing his position to determine the company's future without the support of AVIC Ltd.'s executives. The lack of communication between branch managers and those of the company at a central level led investigators to suspect that serious corruption may have occurred when transferring shares. This was compounded by another suspicious situation: a month before the agreement between Hongyuan and the investment fund, on November 9, 2010, Wu announced an investment of 6.5 billion RMB in the Xi'an economic development zone to build the AVIC Industrial Park, where he intended to install a forging center for the processing of special materials, a physical and chemical testing center, and a center for the development of industrial projects. Later, in December 2012, AVIC Ltd.'s board of directors approved an agreement with the Hongyuan branch to build a forging center in the industrial park.

Despite this, the actual situation in the industrial park was completely different, which was only discovered in 2014 after $\mathrm{Wu}$ was subjected to the "dual regulation" regime. Journalists visited the Xi' an economic development zone and discovered that Shaanxi Hongyuan had commissioned the forging center without starting any remaining projects. The field in which the plants should have been placed was overrun with weeds, leading an AVIC employee to declare, "The idea of Wu would have been very good and far-sighted, but in reality many projects have not been carried forward." Xi'an Sanjiao shareholders also expressed concern about the situation: "The situation in Xi'an's economic development zone is very worrying, the AVIC Ltd. extends over a vast area, but the investment has not been completed. Now $\mathrm{Wu}$ Hao has problems and for the missing part of the project you do not know what will happen".

However, Wu did not seem to be solely responsible for company corruption and abuse of "privileged information" (zhengquan neimu jiaoyi), for which the company received a heavy administrative penalty from the Chinese Securities Regulatory Commission. Even before AVIC Ltd. made its restructuring project known, former company president Zhao Guibin had already conducted telephone conversations with his business partner Zeng Lin to promote his new company. The Commission decided to confiscate about 4 million RMB from Zeng's company, who also received a received a formal warning and was forced to pay a fine of $100000 \mathrm{RMB}$. On May 14, 2013, at the end of this affair, AVIC Ltd. appointed Meng Xiangkai as president in place of Zhao.

While it was not yet known whether Wu had actually obtained money through corruption, he was certainly involved in episodes of "strategic corruption" (juece fubai). This term is often used in China to refer to state-owned military enterprises executives who make deliberate choices in allocating funds to invest in international business. In these cases, their personal decision-making power is exploited to develop projects that have nothing to do with the public interest but instead are aimed at achieving personal or small-group goals. This type of decision-making corruption may not be related to pecuniary benefits, as in the case of the investment allocated by Wu for the industrial park. China had devoted great effort to solving the problem of corruption from an economic viewpoint but had not yet succeeded in addressing the problem in terms of decision-making strategies. This type of corruption is far more damaging to state coffers and can result in the loss of assets worth hundreds of millions of RMB. In 2005, according to a central government report, this type of abuse would have resulted in a total loss of as much as 14.5 billion RMB. Over the course of the trial, even people who should have watched over Wu's work were punished, according to the principle known as "one case and two controls" (yi an shuang cha). On January 25, 2016, the online edition of Renmin Ribao announced that Party executives should have monitored Wu's work within AVIC Ltd. and would be severely punished for the events under investigation.

\section{Causes of corruption and possible countermeasures}

Corruption in Anhui and AVIC Ltd. followed the general pattern of state-owned military enterprises, but unveiled specific problems:

1) collusion between company directors and government officials;

2) monopoly of state enterprises in the military sector (i.e., the army purchases armaments exclusively from state 
enterprises);

3) the dual roles of managers of military state enterprises (i.e., managers often serve as company chairmen and secretaries of the party cell appointed to control the work);

4) the prevalence of guanxi, which facilitates corruption even when some managers are no longer in office or are retired;

5) the use of family relationships by managers of state military enterprises to conduct illicit business;

6) collusion between individuals inside the company who commit fraud, and the dubious quality of military products purchased by the Chinese army;

7) the secrecy of state enterprise archives;

8) assessing managers' economic responsibility in the audit system;

9) inadequate measuring of salary increases and lack of transparency in remuneration mechanisms;

10) hitches in reorganization and restructuring of state companies;

11) bribes invested in real estate; and

12) the system of declaration of ownership of public employees must be improved.

These case studies underscore common issues across episodes of corruption, and some of the points are analyzed below, along with possible solutions to stem corruption. In China, there are two types of monopoly: market and administrative. However, the monopoly is essentially administrative, where the government and some subordinate entities use their power to limit competition in a given sector. This practice has severely compromised the development of military industries, undermining their competitive capabilities in the market. Furthermore, over-reliance on state support increases the likelihood that corporate executives will abuse their power and engage in corruption, thus diminishing the degree of public confidence in the government. The monopoly by state-owned military companies has prevented sectoral development, prompting the Chinese government try to introduce new mechanisms to foster a competitive free market system (Hassard, 2010).

Along with this, military state enterprises can keep information confidential, an advantage that enables the spread of malfeasance and represents a disparity with the management of private military companies; private military companies are considered real auxiliary companies, as they do not completely assume the burden of production processes but only supply the parts necessary for the state industry. Over the past years, with Xi Jinping's work to control the CCP and because of its close ties with the military, changes in this direction have expanded. What was originally an attempt to develop "civil-military integration" has now become "deepening the development of civil-military integration" (shenru shishi junmin ronghe fazhan), marking a greater effort in Chinese policy to support this process. In terms of effective integration of Chinese private military companies into the national defense industry, time has been needed to realize effective institutional change that would allow the opening of the military market to private companies. To achieve this, the country must begin to establish precise market rules and improve the competitive capacity of companies in the sector.

Another complex problem at the root of corruption concerns officials' dual roles. Managers can serve as company president, and as secretary of the internal party cell within the company, functioning as both controllers and the controlled. These conflicts of interest are difficult to manage due to the diversity of roles the individual has to play: the party secretary, who is the political core but also supports business managers, must supervise production and commercial activities; the company owner is responsible for the production cycle and marketing of products, and maximizing company productivity and profits. The introduction of a system of dual positions could help tackle this by ensuring two distinct figures are in charge of business management from economic and political perspectives, in accordance with the CCP's criteria. The role of the secretary would be held by a member of the CCP, while a different person would be president. As the Anhui corruption episode illustrates, dual roles can inhibit the development of Chinese military companies because corruption is largely enabled by such a system, as can be seen by Huang's freedom to act without supervision (Wang Kun, 2015). The transformation of this system could contribute greatly to the resolution of corruption in Chinese military enterprises: dual roles would allow for better control and more effective management by the CCP of military enterprises, ensuring that a company focuses on its economics but respects political criteria dictated by the Party (Qi, 2015). If a CCP member must assume a secretary position, then this same person should not also be company president. For military enterprises that deal with national defense, dual roles are positive and could guarantee healthy and controlled development of enterprise politics (Zhong Zuxun, 2013). As far as the economic development of military enterprises is concerned, the concentration of power in one person incentivizes corruption.

In the last century, the Chinese government carried out two large-scale reorganizations of state-owned military 
enterprises, in 1993 and 1999. With the second reform, the government significantly reduced state intervention in the management of military companies, which can now operate with a greater level of independence. However, the "reorganization and restructuring" (chongzu gaizhi) was tempered in many cases by episodes of significant corruption that resulted in squandering of state assets (Biao, 2012). Thus, the completion of this project still presents several difficulties and problems.

Overall, the main causes of corruption during the reorganization and restructuring process can be grouped into three macro-areas:

1) Lack of clarity regarding ownership of these companies. The state is effectively the possessor of state-owned military enterprise property, but for many analysts, this undermines proper management of the companies in question. One of the most commonly proposed solutions to corruption involves dividing a certain amount of corporate assets into shares to be able to take responsibility for those who administer state property.

2) Incomplete legislation around the restructuring of state-owned military companies. So-called "blind spots" (kongbai dian) in the law, or regulatory gaps, inhibit change and create conditions leading to a loss of state assets. We must also consider cases of lax application of the rules and a tendency not to follow correct procedures. The latter constitutes a typically Chinese phenomenon, which can contribute to corruption.

3) The management structure of these companies is imperfect and ineffective. In the process of military corporate restructuring, the government has slowly afforded businesses increasing power but has generally not established any internal oversight structure: the boards of directors are often fraudulent, unsuitable, and ineffective. Managers have therefore not changed their traditional approach to business management and are accustomed to "wearing new shoes to walk the old road" (chuan xin xie zou jiu lu).

To address these problems, and thereby reorganize state-owned military enterprises or improve the market economy, it is necessary to apply a modern system of property rights to military companies and clearly delineate responsibility. A "clear separation between the government and the company and scientific management of the company" is needed (chanquan qingxi, zequan mingque, zhengqi fenkai, guanli, kexue), a system in which shareholders' meetings, the board of directors, and the supervisory board monitor each other. Loss of state assets due to mismanagement and corruption damages national interests and social justice, and halts public company reform. Blocking corruption is therefore a fundamental objective of the restructuring process, which requires improved control of the management and legal systems.

For historical reasons, state-owned military enterprises are not yet completely independent in terms of internal management and remuneration distribution. Until 1978, they followed the principles of the planned economy and determined managers' compensation solely on administrative title and qualifications (Tan, 2009). This has been described as either "eating from the public cauldron" (da guofan), a metaphor describing egalitarianism in compensation distribution, or as "whether you do good or bad, more or less, it's okay anyway" (gan hao gan huai yi ge yang, gan duo gan shao yi ge yang), reflecting how wages were paid by the state to companies with no connection to operating results. This system did not stimulate enthusiasm for production or worker initiative and creativity, leading to sizeable losses in economic vitality.

Although 40 years have passed since the introduction of market economy principles, the compensation system for managers of state-owned military enterprises has not changed significantly. In some companies, the gap between the incomes of various internal figures is still too broad and does not correspond proportionally to skills, thus inhibiting wage reform, and it will take time for compensation to depend on individual productivity and a principle of fairness. China does not have a unified structure for annual compensation, and every state-owned military enterprise operates according to different criteria.

Among proposals to address corruption in military companies, a motion known as "wage increases to avoid corruption" (gaoxin yanglian) was recently put forward, based on the premise that officials earning higher incomes are less corruptible. However, the reality is far more complex. Despite the large salaries granted in 2014, more than 70 state managers have been fired or investigated, suggesting that high compensation is insufficient to eliminate corruption. Wu was the key figure in a serious corruption case despite having received a gross salary of 630,000 RMB in 2013 as a former deputy general manager of AVIC Ltd., an increase of about 37 thousand RMB over the previous year. In comparison, in 2014, the average individual income among Beijing residents was about 49,730 RMB, 12 times lower than Wu's.

Improvements to incentive mechanisms, internal control, external procedures, and wage adjustments are a 
prerequisite for implementing good remuneration for the managers of state-owned military enterprises. The SASAC regulation states that managers' earnings cannot exceed 14 times workers' average wage, although some experts believe this criterion is contrary to the rules of a market economy, where managers should be rewarded according to economic results, with no ceiling.

Another suggestion is the institution of a committee for personnel evaluation, such as a monitoring body. Recently, some boards of directors have established such committees as a pilot test, but the results have been unsatisfactory. To establish an evaluation system that is as systematic as possible and leaves little room for ambiguity, it is important to consider political and economic criteria, while prioritizing results. A complete evaluation should apply quantitative principles to measure performance in a standardized way and determine corresponding payments.

Corruption also seems to be influenced by some characteristics of traditional Chinese culture. A Chinese expression describes the pragmatic nature of relationships: "friendship can be sought, donated or bought" (mai ge renqing, song ge renqing, qiu ge renqing), just like an exchangeable good (Yan, 2012). If a Chinese person is in debt to someone, he experiences loss of balance and a dependency in interpersonal relationships, which damages his dignity and social status. The person who becomes the beneficiary of such attention can only accept the gift and must reciprocate. Although in theory this is in the private sphere, this situation crosses partly into public life and results in overlap between the two spheres. The network of externalities is configured on private norms, suitable for personal relationships. Crossing borders, beyond which the individual/citizen alienates his responsibilities, relegates individuals to poor social functioning in states and institutions (Yang, 2015). If an individual breaks an agreement, he is not subject to legal condemnation, but social condemnation can be just as strong, if not more so. Disapproval of the person's behavior can generate enormous discomfort because it makes the person a "reprehensible and ungrateful" being (huі zио ren). The consequences are considerable from a practical perspective: the individual may be limited professionally, excluded from relationships, and undermined by a sense of inadequacy and anxiety. The state should provide support at various levels in these cases, because ending the phenomenon requires action to address its causes (Yue, 2013).

Ethical and social problems are even more evident when corruption takes on a familial character. The Chinese are profoundly influenced by the paradigm of guan benwei: individuals who become officials acquire enormous power, including in symbolic and relational points of view. Some leaders use these roles to enrich their relatives, while others may firmly believe that, as they make important contributions to the institution, they can appropriate resources freely. Managers' relatives have been involved in numerous illegal activities, including rigging funds, exchanging favors through nominees, and assisting in opening companies and obtaining orders (Lau, 2013). To counteract this, it is necessary to implement a system to verify company registration among managers' relatives, and assess conflicts of interest. Some scholars have also suggested establishing a system for verifying the company registration of relatives of the leading cadres. The departments responsible for promoting or removing cadres should be able to assess relatives' conflicts of interest and act promptly before corruption emerges. A code of conduct should also be developed for leaders at all levels, who must resist the temptation to accept illicit money. The formation of such measures would be fundamental in helping individuals reflect on the meanings of their roles and those of family in Chinese society, as corruption has often also involved individual's families.

The hierarchical mentality of Chinese authority also warrants further reflection. Military enterprise managers often continue to exercise their authority even after retirement, while an official near retirement is still a powerful figure among his subordinates, able to influence them and condition their morals (Zhang Dan, 2007). The risks associated with a crime are passed down to a latent figure, almost absent, from which comes a common thread linking former officials of new cadres in a relationship of power inversely proportional to the current one. The less authority retired officials possess within the institution, the more authority they wield over future managers, as it is easier for them to get commissions recorded as consultancy fees $(\mathrm{Xu}, 2015)$. The outgoing official has built a relationship of solidarity and deference, often guaranteeing favorable positions, facilitating the handover, and consolidating power networks. His judgment also carries weight over his successor's potential career. The retired official should instead be valued for his experience and put in a position to work for the good of the institution. Without this combination of old and new staff in a constructive dialogue, the retired official and the incumbent will instead find themselves colliding. Problematically, in general, no new official has the strength to report corrupt behavior or an interest in doing so, as it may be improper. The outcome of this is a corruption-collusive system.

This was the case in Anhui, as seen in the relationship between Zhang and his successor Huang. In 2010, Zhang retired and Huang became president, but while Huang may have suspected Zhang's corrupt activities, he did not adopt any preventive measures. It was only in 2013, when Huang was investigated, that Zhang's corrupt activity was 
reported, which otherwise probably would have continued unabated.

There are three possible solutions: accelerated reforms to the system of management cadres, improvements to the legal system in terms of control over non-incumbent cadres, and more investigations of possible corruption by retired cadres (Tang, 2016). Official efforts have aimed to improve the legislation and enforcement of existing laws in cases of corruption by retired cadres (Fan, 2014). In addition to introducing new regulatory provisions, the bodies responsible for monitoring must also enforce the enacted legislation. This is only possible with careful evaluation and research, and it is therefore essential to invest in training to improve the monitoring process.

Another important element involves misappropriated housing, which has seen an exponential increase with the rise in real estate market prices. Until the housing system reform in 1998, managers of Chinese companies enjoyed housing free of charge, but after 1998, a newly instituted law resulted in housing-related corruption (Wang Yaping, 2001). Some state-owned military enterprises executives, accustomed to receiving homes home without paying, tried to continue enjoying this privilege by occupying public buildings with their nominees or buying real estate at prices far below market value. In the case of Anhui, Zhang accepted Chen's suggestion to use fake invoices to pay a down payment for Zhang's son's house. There is no effective system providing data for this type of housing, thereby facilitating abuse (Wang Tao, 2016). The state should outline specific provisions regulating housing use and exit mechanisms, to prevent officials from continuing to occupy housing or otherwise using it improperly following promotion or headquarter relocation. In many cases, public managers have used their privileged position to appropriate funds in the construction sector; in response, the state has created a system to record the official residences of managers of state-owned companies.

After the 18th National Congress of the CCP, government's anti-corruption efforts were intensified to "hit the tigers and drive away the flies" (da hu pai ying), according to a strategy promoted by President Xi Jinping. The tiger symbolizes the upper echelons of the corrupt, and more than 50 "military tigers" have fallen, (e.g., Xu Caihou, Guo Boxiong and Gu Junshan); meanwhile, the fly denotes low-level executives such as in the military enterprise (e.g., Huang Xiaohu, Wu Hao, and Zhang Youren). Corruption in military enterprises is intimately linked to military corruption, which is tied to supplies from military companies. Some successful ways that corruption was fought in the military can be used for reference.

On May 7, 2014, Jiefangjun Bao revealed a document from the Central Military Commission of the CCP on how to "further promote work planning and establish a system of prevention of corruption" (Shenru Tuijin Jundui Chengzhi and Yufang Fubai Tixi Jianshe Gongzuo Guize). The article explained how the document is a demonstration of the CCP's decision to strengthen army discipline, and establish a system to prevent corruption, and anti-corruption efforts have continued within the CCP and army with significant results. The Central Military Commission issued a series of documents and regulations aimed at improving the army's anti-corruption system on the basis of fundamental principles: the work of anti-corruption bodies must not have limits, must not limit its actions in view of individuals' positions of power, should not be time-limited, should consider corrupt individuals who have retired, must not have regional borders, and must apply at both national and local levels.

Today, the Chinese army faces two battlefields: the military struggle (junshi douzheng zhanchang) and the fight against corruption (fan fubai douzheng zhanchang). In the second battle, the Chinese army should be on the front lines to provide support at the local level and set a good example in the fight against corruption. The Central Military Commission's decisions are attempts to combine the military tradition of the Maoist army with innovation in the contemporary era. The fight against corruption in the army therefore requires ideological education and stronger military institutions, a long-term commitment to be pursued by the upper hierarchies of the CCP.

\section{Conclusions}

Government's attempts to fight against corruption, strongly implemented by CCP leadership since the end of 2012, have facilitated development of a broad line of inquiry concerning the illegal activities of business leaders in the Chinese state military (Holmes, 2012). Investigations have produced convictions, and legal procedures have uncovered a consolidated and systematic corruption network, as detailed in this work. Specialist industry sources, court judgments, and many journalistic investigations were consulted to analyze two corruption cases between 2013 and 2015. These events saw a subsequent strengthening of the fight against corruption (Quah, 2015). While the cases analyzed are unique, they contribute to a fuller picture of corruption in China, and this research could be expanded through analyses of other cases. Other interesting episodes in the fight against corruption and the development and transformation of military companies emerged after 2015. For instance, the media publicized a case in December 
2015 concerning the head of the General Department of Armaments, Li Mingquan, who helped a private company obtain military orders and received more than 1.4 million RMB in return. This case exemplified the bonds of malfeasance among army exponents and the managers of state and private military companies and highlighted the evolution of corruption. The combination of the private and public sectors has been merely noted within this work and could be an interesting starting point for future research. Subsequent studies could also examine significant cases of corruption before 2012 to compare the attitudes and political will of CCP leadership over the years.

Finally, this study could represent the starting point of comparative research on corruption in military enterprises in China and abroad. Although China's main military enterprises are state-owned, while those in other countries are often private, corruption in this field is diverse, and media outlets have reported episodes in Germany, Russia, and South Korea. In South Korea, malfeasance and corruption have often characterized the assignment of military contracts over the years, owing to excessive secrecy and limited transparency in its political system. As a rule, military procurement projects are first approved within the state budget, after which responsibility is delegated to military companies and arms trade agencies. Sector representatives are often high-ranking retired military officers who have maintained strong ties with the army. Therefore, they can take advantage of their network and government support to import military products, sometimes commanding high commission costs and huge profits. Studies on these topics may highlight possible causes of illicit and corrupt acts, while identifying potential solutions that could be applied to a complex context, such as in the PRC.

\section{Funding}

Strategic Economy and Civil-Military Integration Interdisciplinarity (Beijing Universities Advanced Disciplines Initiative, No. GJJ2019163).

\section{References}

Biao Xiaohui. (2012). "Guoyou Qiye Gaizhi Guochengzhong of Zichan Liushi Wenti Tanjiu" (Investigation of the problem of loss of funds in the process of restructuring state-owned enterprises). Keji Xinxi, n. 4, pp. 152-153.

Edward X. Gu. (2002). "The State Socialist Welfare System and the Political Economy of Public Housing Reform in Urban China". Review of Policy Research, n. 2, pp. 179-211.

Fan Wei. (2014). "Woguo Tuixiu Falv Zhidu de Yushe Qiand Jiqi Fansi" (Assumptions and reflections on the legal system of Chinese retirement), Zhongguo Renmin Daxue Xuebao, n. 5, pp.107-116.

Hassard John. (2010). "China's State Owned Enterprises: Economic Reform and Organizational Restructuring”, Journal of Organizational Change Management, n. 5, pp. 500-516.

Holmes Leslie. (2015). "Combating Corruption in China: The Role of the State and Other Agencies in Comparative Perspectives". Journal of Economic and Political Studies, n. 1.

Lau Kun Luen Alex, Angus Young. (2013). "Why China Shall Not Completely Transit from a Relation Based to a Rule Based Governance Regime: A Chinese Perspective”. Corporate Governance: An International Review, n. 6, pp. 577-585.

Lin Yifu, Cai Fang. (1998). "Competition, Policy Burdens, and State-Owned Enterprise Reform”. The American Economic Review, n. 2, pp. 422-427.

Luo Yadong. (2008). "The Changing Chinese Culture and Business Behavior: The Perspective of Intertwinement Between Guanxi and Corruption”. International Business Review, n. 17, pp. 188-193.

Qi Guan. (2015). "Xinshiqi Guoqi Shengai ying Caiqu Dangzheng Fenli” (A thorough reform of state enterprises should imply a separation between politics and party. Guoqi, n. 12, pp. 23-26.

Quah Jon ST. (2015). "Hunting the Corrupt Tigers and Flies in China: An Evaluation of XI Jinping's Anti-Corruption Campaign (November 2012 to March 2015)". Maryland Series in Contemporary Asian Studies, n. 1, pp. 1-98.

Tan Justin, Jun Yang, Rajaram Veliyath. (2006). "Particularistic and System Trust Among Small and Medium Enterprises: A Comparative Study in China's Transition Economy". Journal of Business Venturing, n. 6, pp. 544-557.

Tang Huangfeng. (2016). "Woguo Dangzheng Lingdao Ganbu Xuanba Renyong Zhidu de Tiaoshi yu Youhua" (Adjustment and optimization of the system of selection and appointment of Chinese cadres). Zhonggong Fujian Shengwei Dangxiao Xuebao, n. 8, pp. 37-43. 
Wang Kun. (2015). "Fubai Jiegai Guoqi Zhili Quexian" (Deficiencies of governance of state companies lead to corruption). Dong Shihui, n. 2, pp. 37-38.

Wang Mingsong. (2015). Lengzhanhou Zhonge Wuqi Maoyi Yanjiu (Research on arms trade between China and Russia after the Cold War). Wuhan, Huazhong Shifan Daxue Chubanshe.

Wang Tao. (2016). "Case Study of Integrated Prefab Accommodations System for Migrant On-Site Construction Workers in China". Journal of Professional Issues in Engineering Education and Practice, n. 4, pp. 92-108.

Wang Yaping. (2001). "Urban Housing Reform and Finance in China A Case Study of Beijing”. Urban Affairs Review, n. 5, pp. 620-645.

Xu Sulin. (2015). "Jingti Tuixiu Guanyuan Quanli Yure Xianxiang" (Watch out for the excess power of retired officials). Jiancha Fengyun, no. 14, pp. 15-16.

Yan Yanshi. (2012). Woguo Jiceng Gongwuyuan Renqing Fubai Zhili Yanjiu (Research and treatment of corruption of human relations among Chinese civil servants), Fuzhou, Fujian Normal University Press.

Yang Guorong. (2015). "Quanli yu Yiwu Wenti Shang de Shiyu Zhuanhuan yu Shiyu Ronghe" (Conversion and integration of rights and obligations). Zhexue Yanjiu, n. 4, pp. 47-56.

Yue Lei. (2013). Woguo Fubai Xingwei de Guanxi Yanjiu (Research on reports on corruption in China), Wuhan, Central China Normal University Press.

Zhang Dan. (2007). Shilun Dangdai Zhongguo Fanfu de Chengyin Jiqi Zhiduxing Duice (On the causes and institutional countermeasures of contemporary corruption in China), Beijing, China University of Political Science and Law Press.

Zhang Xingguo. (2008). Zhongguo Minying Qiye Jinru Jungong Chanye de Zhanlue Sikao (The strategy of Chinese private enterprises to enter the military industry), Shanghai, Fudan University Press, p. 7.

Zhong Zuxun. (2013). "Congyan Guifan Lingdao Ganbu zai Qiye Jianzhi Renzhi” (Regulate severely executives who hold part-time positions in the company), Dangjian Wenhui Yuekan, n. 12, p. 19. 